\title{
Analysis of the necessity of routine tests in trauma patients in the emergency department
}

\author{
Acil servise başvuran travma hastalarında rutin testlerin gerekliliğinin analizi
}

\author{
Özlem KÖKSAL, Şebnem EREN ÇEVİK, Şule AKKÖSE AYDIN, Fatma ÖZDEMİR
}

\section{BACKGROUND}

The necessity of routine tests as regarded in the Advanced Trauma Life Support protocols has become controversial in recent years. The aim of this study was to analyze the necessity of routine tests in trauma patients.

\section{METHODS}

This was a prospective study. A total of 103 blunt trauma patients aged between 15 and 65 years who presented to the emergency department with major trauma, Glasgow Coma Scale of 15 and Revised Trauma Score of 12 were admitted to the study.

\section{RESULTS}

The average age of the patients ( $30.1 \%$ female, $69.9 \%$ male) was $35 \pm 12.97$ years. A total of $72.8 \%$ of the patients presented for motor vehicle crashes, $12.6 \%$ for pedestrian injury and $14.6 \%$ for fall from a height. All of the routine tests were evaluated separately. With the exception of cervical examination-lateral cervical X-ray results and pelvic examinationcomplete blood count and urinalysis test results, significant relations were determined between the reason for requiring a test and the results of the other tests (complete blood count, lateral cervical X-ray and abdominal ultrasonography).

\section{CONCLUSION}

According to our study, biochemical tests, anterior-posterior chest X-ray and anterior-posterior pelvic X-ray can be ordered as targeted tests. Conducting targeted tests will reduce costs and workload.

Key Words: Major trauma; routine tests; reason for requirement; targeted test.

\begin{abstract}
AMAÇ
Son y1llarda ileri travma yaşam desteği protokollerine göre rutin testlerin gerekliliği tartışılmaktadır. Bu çalışmanın amac1, majör travma hastalarında rutin testlerin gerekliliği ve tanısal değerini analiz etmektir.
\end{abstract}

\section{GEREÇ VE YÖNTEM}

Bu prospektif çalışmada, Glasgow Koma Skoru 15, Revize Travma Skoru 12 olan ve 15-65 yaş arası majör travma ile acil servise başvuran toplam 103 künt travma hastası değerlendirildi.

\section{BULGULAR}

Hastaların (\%30,1 kadın,\%69,9 erkek) yaş ortalaması $35 \pm 12.97$ idi. Tüm hastaların $\% 72,8$ 'i araç içi trafik kazas1, \%12,6's1 araç dışı trafik kazası ve \%14,6's1 yüksekten düşme ile başvurdu. Rutin testlerin hepsi ayrı ayrı değerlendirildi. Servikal inceleme ile lateral servikal röntgen istemi, pelvik muayene ile tam kan sayımı ve idrar testi istemi hariç, tam kan sayımı, yan servikal röntgen ve karın ultrasonografisi istem nedenleri ile diğer test sonuçları ve istem nedenleri karşılaştırıldığında önemli farklılıklar saptandi.

\section{SONUÇ}

Çalışmamıza göre biyokimyasal testler, ön-arka göğüs grafisi ve ön-arka pelvis grafisi hedefe yönelik testler olarak istenebilir. Hedefe yönelik testlerin istemi ile maliyet ve iş yükü azalacaktır.

Anahtar Sözcükler: Majör travma, rutin testler, istem nedeni, hedefe yönelik test. Bursa. 
Trauma is the leading cause of death in the population of patients aged less than 45 years. ${ }^{[1]}$ Overall, $50 \%$ of deaths in the age group under 14 years, $80 \%$ of deaths in the age group $15-24$ years and $65 \%$ of deaths in the age group 25-40 years are caused by trauma. ${ }^{[2]}$ Therefore, most young and healthy patients should be carefully examined for masked injury. In accordance with the primary problem of the patient, the most appropriate laboratory and screening tests should be ordered. Medical knowledge, habits, local customs, institutional policies, and legal concerns may affect the physician's decisions about the diagnostic tests. Tests are done for many reasons; however, the most important reason is to facilitate the patient's treatment. ${ }^{[3]} \mathrm{On}$ the other hand, the diagnostic accuracy of tests may not be clear when they are ordered. Another issue is the time spent for the tests. Time spent on unnecessary tests has significant importance in the emergency department (ED). Finally, each test has a cost. ${ }^{[3]}$ Rising costs and increasing demand for the limited resources of trauma care threaten the viability of trauma programs. ${ }^{[4]}$ In current practice, because treatment periods are long and costs are high, the situation worsens when unnecessary X-rays and laboratory tests are ordered. Nowadays, there is a trend to reduce whenever possible the number of X-rays and laboratory studies ordered. ${ }^{[5]}$

Advanced Trauma Life Support (ATLS) protocols, which are prepared by the American College of Surgeons, are standardized protocols for the management of trauma patients, which present a concise approach for the assessment and management of multipleinjured patients. ATLS protocols are revised by the ATLS subcommittee approximately every four years. ${ }^{[6]}$ According to ATLS, there are some routine tests in the management of blunt trauma patients. These are hemoglobin or hematocrit values, biochemical tests that consist of liver and renal function tests, urinalysis, anterior-posterior chest X-ray, anterior-posterior pelvic X-ray, lateral cervical X-ray, and focused assessment sonography in trauma (FAST). Today, the diagnostic value, necessity and cost of routine trauma tests, which are ordered for trauma patients who meet the criteria of major/multiple trauma and have no pathologic signs in the physical examination, are being scrutinized. There are very few studies in this context, and these studies are mostly about the necessity of isolated cervical or pelvic X-rays or the costeffectiveness of the trauma tests.

In this study, routine laboratory and radiologic tests in patients who presented to our ED with major trauma were analyzed. Every unnecessary test causes additional burden with respect to either time or medical expenditures in trauma patients. The aim of this study was to analyze the necessity and diagnostic value of routine tests in major trauma patients with a Glasgow Coma Scale (GCS) of 15 as well as a Triage-Revised Trauma Score (T-RTS) of 12, and to gain a new point of view for the assessment of trauma patients.

\section{MATERIALS AND METHODS}

This was a prospective observational study performed from February 1, 2009 through June 30, 2009 at the Uludag University Faculty of Medicine Hospital ED, following the ethics committee approval (approval number: 2009-2/26). A total of 103 blunt trauma patients aged between 15 and 65 years who presented to the ED with motor vehicle crash, pedestrian injury or fall from a height, with a GCS of 15 and a T-RTS of 12 , corresponding to major trauma criteria of ATLS according to the mechanism of occurrence, and who voluntarily enrolled were admitted to the study. Major trauma criteria according to the mechanism of occurrence were accepted as ejection from auto, death in the same passenger compartment, pedestrian thrown or run over, high speed auto crash (initial speed $>64 \mathrm{kph}$, major auto deformity $>50 \mathrm{~cm}$, intrusion into passenger compartment $>30 \mathrm{~cm}$ ), extrication time $>20 \mathrm{~min}$, falls $>3 \mathrm{~m}$, rollover, auto-pedestrian injury with $>8 \mathrm{kph}$ impact, and motorcycle crash $>32 \mathrm{kph}$ or with separation of rider and bike. Patients with GCS $<15$, T-RTS $<12$, age $<15$ or $>65$ years, or who were intoxicated were excluded from the study.

The trauma patients' data were recorded on the "Trauma Patient Assessment Form" by a resident physician of emergency medicine. Whether or not the patient was in shock was determined by examining blood pressure, pulse rate, respiratory rate, T-RTS, and the general condition of the patient; these values were noted on the form. After the initial assessment of the patient and the organization of diagnostic tests, it was ensured that the form was filled out, and the results and consultations recorded by the resident physician. In the thorax-cardiovascular system, abdominal, and genitourinary system examinations, the existence of lesions, ecchymosis, abrasions, and lacerations was inspected, lung and heart sounds were auscultated, and the presence of crepitation and tenderness was investigated with palpation on thorax examination. The presence of hematoma and hematochezia was investigated on rectal and genitourinary examination. A neurologic examination was also conducted; crepitations, deformities, subcutaneous hematomas, and lacerations on the scalp and face were examined. On muscle and skeleton system examination, deformities, tenderness and crepitations were examined. The existence of any of these was accepted as a positive finding. In the examination of patient, the positive findings were recorded on the form by the resident physician. The positive findings are shown in Table 1. On the form, three options were presented for recording the under- 
Table 1. Positive findings on physical examination of trauma patients

\begin{tabular}{cc}
\hline Positive findings & $\begin{array}{c}\text { Number of } \\
\text { Patients }\end{array}$ \\
\hline
\end{tabular}

Abnormal lung sounds, tachypnea 3

Tenderness on thorax with palpation

Tenderness on abdominal examination

Laceration, ecchymosis or abrasion on abdomen

Laceration, ecchymosis or abrasion on thorax

Tenderness on pelvis with palpation

Tenderness on thoracal/lumbar vertebrae with

palpation

A cut or abrasion on the scalp or face

on scalp or face

Amnesia, nausea, emesis

Epistaxis

Tenderness, hematoma or ecchymosis

on genitourinary region

No positive findings

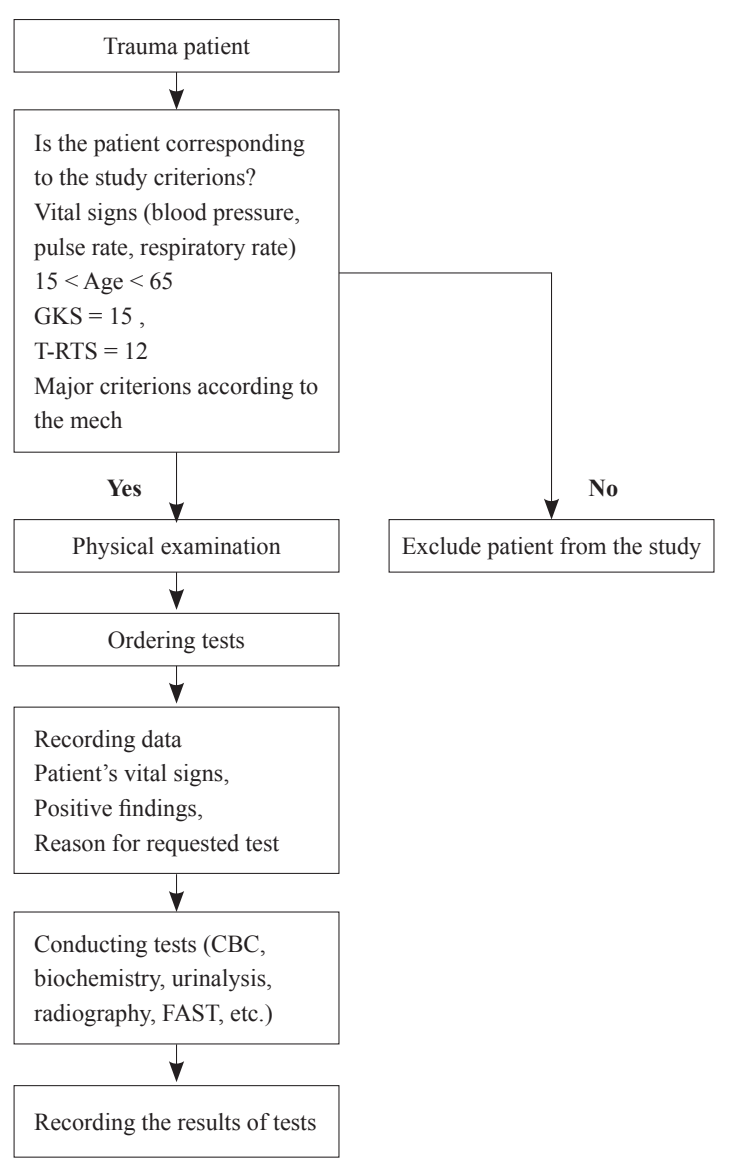

Fig. 1. Flow of the study. lying reason for the requested test for the trauma patient, and the resident physician was asked to select one of them. These options and the leading conditions were as follows: In the physical examination, if no pathology was determined, but the test was ordered as a routine trauma test, then the resident physician was requested to select the option "I do not suspect a pathology, but I request this test because it is routine." In case no specific or significant pathological finding was determined in the physical examination, but the resident physician could not clarify that there was no pathology, then the doctor was requested to select the option "I'm not sure". Finally, if a significant abnormal finding was determined in the patient's physical examination, then the doctor was requested to select the option "I suspect a pathology". The flow of the study is shown in Figure 1.

For statistical analyses, SPSS 13.0 (Statistical Package for the Social Sciences for Windows) software was used. According to the characteristics of the variables that were used in the study, descriptive statistics and frequency distributions were calculated. To compare categorical variables, Fisher's exact test was used in 2x2 tables and Pearson's chi-square test was used in larger tables. Statistical significance was accepted at $\mathrm{p}<0.05$.

One month after the last study patient presented to the ED, all of the records in the University Hospital were examined. It was determined that the study patients presented to the polyclinics due to the previously identified pathologies in the ED; on the other hand, it was determined from the records that no additional pathologies regarding the trauma were found.

\section{RESULTS}

A total of 103 blunt trauma patients aged between 15 and 65 years who presented to the ED from February 1, 2009 through June 30, 2009, with a GCS of 15 and a T-RTS of 12 and fulfilling major trauma criteria of ATLS according to the mechanism of trauma were admitted to the study. The average age of the patients who were accepted to the study was $35 \pm 12.9$ years. Most of the patients who were accepted to the study were in their 3rd decade (Fig. 2). Overall, 30.1\% of the patients $(n=31)$ were female and $69.9 \%(n=72)$ were male. The reasons for presenting to the ED were motor vehicle crashes $(72.8 \%)$, pedestrian injury $(12.6 \%)$ and fall from height $(14.6 \%)$. No significant difference was found between the female and male ratios in traffic accidents (motor vehicle crashes, pedestrian injury) and fall from height $(p=0.544)$. The mean Injury Severity Score (ISS) was 5.0 for the patient group admitted to the study.

Not all of the routine trauma tests were ordered for all patients in the study. The decision of which routine 


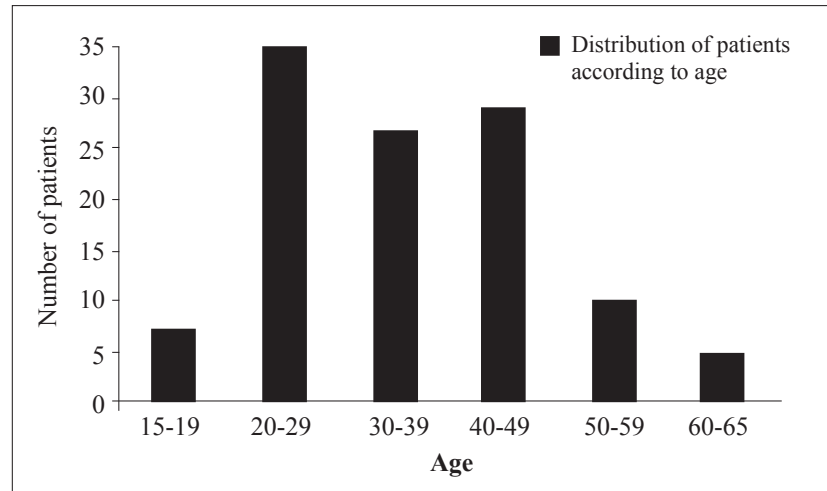

Fig. 2. Distribution of patients' ages by decades.

trauma tests should be ordered for each patient was left to the discretion of the resident physician. Each test was evaluated separately; thus, the number of ordered tests was calculated separately. The number of routine tests ordered and the number of pathologic results are shown in Figure 3.

The Relation between the Physical Examination and Test Results: When the physical examination findings and the test results were compared, the following results were obtained. If there was an injury because of trauma to one or more systems, e.g. the thorax-cardiovascular, abdominal or genitourinary systems, then a decrease in the hemoglobin and hematocrit values may have occurred. Therefore, the three systems were grouped together when the statistical calculation was performed. No significant difference was found between the hemoglobin and hematocrit values and the determination of a pathologic finding in at least one of the systems mentioned above in the physical examination $(\mathrm{p}=0.525)$.

When the aspartate aminotransferase and alanine aminotransferase (SGOT and SGPT) values in a normal abdominal examination and abnormal abdomi-

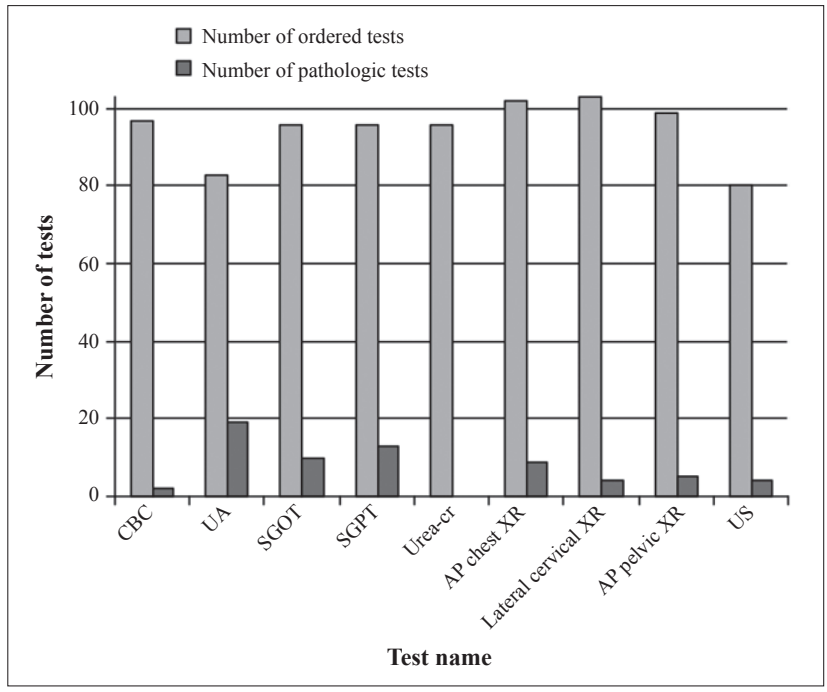

Fig. 3. Ordered tests in trauma patients.

CBC: Complete Blood Count; UA: Urine analysis; SGOT: Serum glutamic-oxaloacetic transaminase; SGPT: Serum glutamate pyruvate transaminase; Cr: Creatinine; AP: Anteroposterior; XR: X-ray; US: Ultrasonography.

nal examination were compared, significant $\mathrm{p}$ values were found $(p=0.024$ and $p=0.020$, respectively). If the physical examination of the thorax and cardiovascular system was normal, the probability of a normal anterior-posterior chest X-ray was significantly high $(p<0.001)$. When cervical examination and lateral cervical X-ray results were compared, no significant difference was found $(\mathrm{p}=0.347)$. As to the comparison of pelvic examination and pelvic X-ray results, if the pelvic examination was normal, the probability of no pathologic finding on pelvic X-ray was found significantly high $(\mathrm{p}=0.012)$. If the abdominal and genitourinary system examinations were normal, the probability of no pathologic finding on abdominal ultrasonography (US) was significantly high $(\mathrm{p}=0.046)$ (Table 2).

Table 2. The relationship between physical examination and test results

\begin{tabular}{|c|c|c|c|c|c|c|c|c|c|c|c|}
\hline & & \multicolumn{4}{|c|}{$\begin{array}{c}\text { Pathologic SGOT and } \\
\text { SGPT value }\end{array}$} & \multicolumn{2}{|c|}{$\begin{array}{l}\text { Pathologic finding on } \\
\text { anterior-posterior } \\
\text { chest X-ray }\end{array}$} & \multicolumn{2}{|c|}{$\begin{array}{c}\text { Pathologic finding on } \\
\text { pelvic X-ray }\end{array}$} & \multicolumn{2}{|c|}{$\begin{array}{l}\text { Pathology on } \\
\text { abdominal US }\end{array}$} \\
\hline & & \multicolumn{2}{|c|}{ Positive } & \multicolumn{2}{|c|}{ Negative } & \multirow[t]{2}{*}{ Positive } & \multirow[t]{2}{*}{ Negative } & \multirow[t]{2}{*}{ Positive } & \multirow[t]{2}{*}{ Negative } & \multirow[t]{2}{*}{ Positive } & \multirow[t]{2}{*}{ Negative } \\
\hline & & SGOT & SGPT & SGOT & SGPT & & & & & & \\
\hline \multirow{2}{*}{$\begin{array}{l}\text { Pathologic } \\
\text { finding on } \\
\text { physical } \\
\text { examination }\end{array}$} & Positive & $\begin{array}{l}5.2 \% \\
(n=5)\end{array}$ & $\begin{array}{l}6.3 \% \\
(n=6)\end{array}$ & $\begin{array}{l}14.6 \% \\
(n=14)\end{array}$ & $\begin{array}{l}13.5 \% \\
(n=13)\end{array}$ & $\begin{array}{l}5.9 \% \\
(n=6)\end{array}$ & $\begin{array}{c}9.8 \% \\
(n=10)\end{array}$ & $\begin{array}{c}2 \% \\
(n=2)\end{array}$ & $\begin{array}{c}2 \% \\
(n=2)\end{array}$ & $\begin{array}{l}3.8 \% \\
(n=3)\end{array}$ & $\begin{array}{l}21.3 \% \\
(n=17)\end{array}$ \\
\hline & Negative & $\begin{array}{l}5.2 \% \\
(\mathrm{n}=5)\end{array}$ & $\begin{array}{l}7.3 \% \\
(n=7)\end{array}$ & $\begin{array}{c}75 \% \\
(n=72)\end{array}$ & $\begin{array}{l}72.9 \% \\
(n=70)\end{array}$ & $\begin{array}{l}2.9 \% \\
(n=3)\end{array}$ & $\begin{array}{l}81.4 \% \\
(n=83)\end{array}$ & $\begin{array}{c}3 \% \\
(\mathrm{n}=3)\end{array}$ & $\begin{array}{l}92.9 \% \\
(n=92)\end{array}$ & $\begin{array}{l}1.3 \% \\
(\mathrm{n}=1)\end{array}$ & $\begin{array}{l}73.8 \% \\
(n=59)\end{array}$ \\
\hline
\end{tabular}

*When a pathologic finding was present on abdominal examination, SGOT and SGPT values were significantly high (p values were 0.024 and 0.020 , respectively). In the event of a normal physical examination of the thorax and cardiovascular system, the probability of not having a pathologic anterior-posterior chest X-ray was significantly high $(\mathrm{p}<0.001)$. When the pelvic examination was normal, the possibility of no pathologic finding on pelvic $\mathrm{X}$-ray was significantly high $(\mathrm{p}=0.012)$. When the abdominal and genitourinary system examinations were normal, the possibility of no pathologic finding on abdominal US was significantly increased $(\mathrm{p}<0.05)$. 
Table 3. The relationship between the reason for requiring tests and their results

\begin{tabular}{|c|c|c|c|c|c|c|c|c|c|c|c|}
\hline & & \multicolumn{2}{|c|}{$\begin{array}{l}\text { Pathologic finding } \\
\text { on urinalysis }\end{array}$} & \multicolumn{2}{|c|}{$\begin{array}{l}\text { Pathologic SGOT } \\
\text { value }\end{array}$} & \multicolumn{2}{|c|}{$\begin{array}{l}\text { Pathologic SGPT } \\
\text { value }\end{array}$} & \multicolumn{2}{|c|}{$\begin{array}{l}\text { Pathologic finding } \\
\text { on anterior-posterior } \\
\text { chest X-ray }\end{array}$} & \multicolumn{2}{|c|}{$\begin{array}{l}\text { Pathologic finding } \\
\text { on pelvic X-ray }\end{array}$} \\
\hline \multirow{4}{*}{$\begin{array}{l}\text { The reason } \\
\text { for requiring } \\
\text { a test }\end{array}$} & & Positive & Negative & Positive & Negative & Positive & Negative & Positive & Negative & Positive & Negative \\
\hline & $\begin{array}{l}\text { Because it } \\
\text { is routine }\end{array}$ & $\begin{array}{l}8.4 \% \\
(n=7)\end{array}$ & $\begin{array}{l}50.6 \% \\
(n=42)\end{array}$ & $\begin{array}{l}2.1 \% \\
(n=2)\end{array}$ & $\begin{array}{l}60.4 \% \\
(n=58)\end{array}$ & $\begin{array}{l}3.1 \% \\
(n=3)\end{array}$ & $\begin{array}{l}59.4 \% \\
(n=57)\end{array}$ & $\begin{array}{c}0 \% \\
(n=0)\end{array}$ & $\begin{array}{l}58.8 \% \\
(n=60)\end{array}$ & $\begin{array}{c}0 \% \\
(n=0)\end{array}$ & $\begin{array}{l}62.6 \% \\
(n=62)\end{array}$ \\
\hline & $\begin{array}{l}\text { I am not } \\
\text { sure }\end{array}$ & $\begin{array}{l}7.2 \% \\
(n=6)\end{array}$ & $\begin{array}{l}24.1 \% \\
(n=20)\end{array}$ & $\begin{array}{l}3.1 \% \\
(n=3)\end{array}$ & $\begin{array}{l}22.9 \% \\
(n=22)\end{array}$ & $\begin{array}{l}5.2 \% \\
(n=5)\end{array}$ & $\begin{array}{l}20.8 \% \\
(n=20)\end{array}$ & $\begin{array}{c}2 \% \\
(n=2)\end{array}$ & $\begin{array}{l}24.5 \% \\
(n=25)\end{array}$ & $\begin{array}{c}2 \% \\
(n=2)\end{array}$ & $\begin{array}{l}25.3 \% \\
(n=25)\end{array}$ \\
\hline & $\begin{array}{l}\text { I suspect a } \\
\text { pathology }\end{array}$ & $\begin{array}{l}7.2 \% \\
(n=6)\end{array}$ & $\begin{array}{l}2.4 \% \\
(n=2)\end{array}$ & $\begin{array}{l}5.2 \% \\
(n=5)\end{array}$ & $\begin{array}{l}6.3 \% \\
(n=6)\end{array}$ & $\begin{array}{l}5.2 \% \\
(n=5)\end{array}$ & $\begin{array}{l}6.3 \% \\
(n=6)\end{array}$ & $\begin{array}{l}6.9 \% \\
(\mathrm{n}=7)\end{array}$ & $\begin{array}{l}7.8 \% \\
(n=8)\end{array}$ & $\begin{array}{c}3 \% \\
(n=3)\end{array}$ & $\begin{array}{l}7.1 \% \\
(n=7)\end{array}$ \\
\hline
\end{tabular}

*When the urinalysis test was ordered because of routine, the possibility of normal urinalysis was increased $(\mathrm{p}=0.02)$. There was a significant difference between the reason for requiring biochemical tests and SGOT and SGPT values ( $\mathrm{p}$ values were 0.005 and 0.003 , respectively). When the anterior-posterior chest X-ray was ordered because of routine, the possibility of non-pathologic finding in the anterior-posterior chest X-ray was significantly high ( $\mathrm{p}=0.0001)$. When the pelvic $\mathrm{X}$-ray was ordered because of routine, the possibility of non-pathologic finding on the pelvic X-ray was significantly high $(\mathrm{p}=0.0006)$.

No significant difference between pelvic examination and hemoglobin-hematocrit values $(p=0.999)$ or between pelvic examination and urinalysis $(p=0.223)$ was found.

\section{The Relation between Reasons for Requirement} and Results of the Tests: No significant difference was found between the reason for ordering a complete blood count (CBC) and the hemoglobin and hematocrit results $(p=0.143)$. When the reason for requiring a urinalysis and the results of the test were compared, it was found that if the resident physician did not suspect a urinary system injury and the reason for requiring the test was because it was routine, then the probability of a normal urinalysis was increased $(\mathrm{p}=0.020)$. A significant difference was found between the reason for requiring biochemical tests and SGOT and SGPT values $(\mathrm{p}=0.005$ and $\mathrm{p}=0.003$, respectively). The reason for requirement and the results of anteriorposterior chest X-ray were compared. If there was no suspicion of any pathologic finding and the reason for requirement of the test was routine, then the probability of a non-pathologic finding in the anterior-posterior chest $X$-ray was significantly high $(p=0.0001)$. There was no significant difference between the reason for requirement and the result of lateral cervical X-ray $(p=0.299)$. We compared the reason for requirement and the results of pelvic X-ray. If there was no suspicion of any pathologic finding in the pelvic X-ray and the reason for requirement of the test was routine, then the probability of no pathologic finding on the pelvic $\mathrm{X}$-ray was significantly high $(\mathrm{p}=0.006)$ (Table 3 ).

There was no significant difference between the reason for requirement and the result of abdominal US $(\mathrm{p}=0.313)$.

As a result, according to our study, hemoglobinhematocrit, urinalysis, lateral cervical X-ray, and FAST should be the routine tests; however, biochemi- cal tests, anterior-posterior chest X-ray and anteriorposterior pelvic X-ray should be the targeted tests in evaluating major trauma patients.

\section{DISCUSSION}

Clinical guidelines are ideal solutions for using laboratory tests. The development of a guideline takes time; however, it eliminates the necessity of the physician's individual assessment of every laboratory testordering decision. ${ }^{[3]}$ On the other hand, it may mean the ordering of an unnecessary test. Screening panels are defined as automatic tests obtained for all trauma patients irrespective of their history or severity of injuries. ${ }^{[4]}$ Recently, the necessity of clinical guidelines in trauma has been discussed. Tasse et al. ${ }^{[4]}$ studied the clinical significance and cost of routine trauma tests over a period of three months. In that study, the greatest cost was for chest X-ray (90\% unnecessary), C-spine X-ray (98\% unnecessary) and pelvic X-ray (94\% unnecessary). In another study, Chu et al. ${ }^{[7]}$ determined that by using selective tests instead of routine tests, the annual savings was $\$ 1.5$ million. In our study, the necessity of routine tests in major trauma patients who presented to the ED for motor vehicle crash, pedestrian injury or fall from height was reviewed and analyzed. The initial routine test in trauma patients is the CBC. Determining occult blood loss is one of the most important components of the evaluation of a trauma patient. Despite large-scaled studies, determining occult blood loss in trauma patients is still an important problem for emergency physicians. The serial hematocrit measurements are part of routine trauma studies in many institutions in the United States. In studies by Snyder et al., ${ }^{[8,9]}$ the sensitivity of the initial hematocrit value for determining intraabdominal and intrathoracic injuries that require operative intervention was $50 \%$, and tachycardia was seen not to be a reliable sign of hypovolemic shock. Furthermore, infusion of intra- 
venous fluids in trauma patients may decrease hematocrit values and make it difficult to assess the hematocrit. ${ }^{[8]}$ Tasse et al. ${ }^{[4]}$ studied CBC tests in 367 patients. $\mathrm{CBC}$ results were abnormal in $42 \%$ of the patients and clinically significant in only $0.3 \%$ of the patients. In our study, the physical examination of the cardiovascular, abdominal and genitourinary systems and CBC values were compared; however, no significant difference was found $(\mathrm{p}=0.525)$.

The abdomen often represents a "black box" with respect to early diagnosis, and failure to appropriately evaluate the abdomen has been identified as the most common error in trauma management. ${ }^{[10]}$ In their study, Michetti et al. ${ }^{[11]}$ determined that in such situations, even when the abdominal examination was completely normal, about $10 \%$ of the patients still had abdominal or pelvic injuries. Furthermore, they pointed out that pain from concomitant injuries and intoxicants were common in trauma patients at the time of presentation. Thus, because of the potential masking effect of distracting pain, alcohol or drugs, the physical examination of the patients in the trauma bay should not be used as the sole screening test to detect abdominal or pelvic injury. Keller et al. ${ }^{[12]}$ determined that children with SGOT and SGPT abnormalities were more likely to have liver injury than children presenting with normal levels. They found that $67 \%$ of the children with SGOT levels greater than $400 \mathrm{U} / \mathrm{L}$ and $78 \%$ of the children with SGPT levels greater than $400 \mathrm{U} / \mathrm{L}$ would have a gradable liver injury $(\mathrm{p}<0.050)$. Karaduman et al. ${ }^{[13]}$ reported that a statistically significant positive correlation was found between radiologically detected intra-abdominal pathology and increased SGOT (above 110.5 U/L) and SGPT (above 63.5 U/L) levels $(\mathrm{p}<0.010$, $r$ values for SGOT and SGPT 0.63 and 0.58 , respectively). In our study, SGOT and SGPT values were measured in 96 patients. Respectively, in 10 and 13 patients, SGOT and SGPT values were pathologic (>60 IU/L). In 60 patients, the reasons for requirement of biochemical tests were because they were routine and there was no expectation of pathologic results. The abdominal physical examination and SGOT and SGPT values were also compared, and a significant relationship was found between them. When the abdominal examination was compared with SGOT values, the negative predictive value (NPV) was measured as 93.5\%; when compared with SGPT values, the NPV was measured as $90.0 \%$. The positive predictive value (PPV) was low (when compared with SGOT values, PPV was $26.3 \%$; when compared with SGOT values, PPV was 31.6\%).

The rate of the occurrence of urinary system injuries after abdominal trauma is approximately $10 \%$. The most widely injured urinary system organ is the kidney, followed by the bladder and urethra. Urinary system trauma rarely occurs in isolation, and when other critically important injuries are given priority, urinary system trauma may escape notice. Hematuria is a nonspecific finding; however, it is the only finding that warns the emergency physician about a urinary system trauma. Hematuria is a characteristic sign of renal trauma, despite a poor correlation with the severity of injury. ${ }^{[14]}$ According to ATLS, urinalysis is one of the routine trauma tests. In our study, urinalysis was studied in 83 patients. Urinalysis was ordered as a routine test in $59.0 \%$ of these patients, and microscopic hematuria (erythrocyte $>10 / \mathrm{hpf}$ ) was determined in $14.3 \%$ of the routine urinalysis tests; however, in $85.7 \%$ of these cases, there was no pathologic finding. There was a significant difference between the reason for requirement of urinalysis and the result of urinalysis $(\mathrm{p}=0.020)$.

$\mathrm{C}$-spine injuries constituted $2-6 \%$ of trauma patients who presented to the ED, and most of the Cspine injuries occurred after traffic accidents or falls from a height. A fast and accurate diagnosis of cervical spine injuries is important because a delayed or undiagnosed, unstable injury can lead to severe morbidity and mortality. ${ }^{[15]}$ In their study, Ersoy et al. ${ }^{[16]}$ diagnosed C-spine injury in 5\% $(n=13)$ of 267 patients, and in all of these injuries, it was observed that there was cervical pain in the history and/or cervical tenderness on examination. In 3 of these 13 patients, there was also a neurological deficit. Fifty-two out of the 267 study patients (20\%) experienced pain and/or tenderness. In 39 patients who complained about cervical pain and/or cervical tenderness with palpation, there was no cervical injury. Bandiera et al. ${ }^{[17]}$ mentioned that $110,000 \mathrm{C}$-spine radiography assessments are done each year in Canada on alert, stable, adult trauma patients, of which $98 \%$ are normal. They also mentioned that the cost of inexpensive, high-volume tests might contribute more to rising health care costs than more expensive high-technology procedures. Duane et al. ${ }^{[18]}$ executed a study of 1004 patients, regardless of GCS; in 84 of these patients, cervical fracture was determined with cervical computed tomography (CT). In 68 of these 84 patients with cervical fracture, C-spine $\mathrm{X}$-ray was not appropriately imaged. They determined that when C-spine X-ray was compared to cervical CT, lateral cervical X-ray had a sensitivity of $19.0 \%$ and a PPV of $69.6 \%$. Because most of the lateral cervical X-rays were performed inappropriately and did not image all the cervical vertebrae, they argued that lateral cervical X-ray in blunt trauma patients has no value as a screening test and should be excluded from the ATLS algorithm. In the 2008 revision of the ATLS algorithm, it was determined that CT may supersede $\mathrm{C}$-spine X-ray in the evaluation of cervical vertebrae. ${ }^{[19]}$ According to Dickinson et al., ${ }^{[20]}$ inefficient use of C-spine radiography wastes health care dollars, pro- 
longs uncomfortable immobilization with hard collars and back boards, results in unnecessary exposure to ionizing radiation, and delays ED discharge. In our study, C-spine X-ray was ordered in 103 patients; in $60.2 \%$ of these patients, there was no pathologic finding on the physical examination and the test was ordered because it was routine. A pathology was identified on C-spine X-ray in only $3.9 \%(n=4)$ of these 103 patients.

Thoracic trauma is the second most common lifethreatening trauma after head trauma. ${ }^{[7]}$ Rezendo-Neto et al. ${ }^{[21]}$ determined that the detection of small amounts of air in the pleural space or in the mediastinum in admission trauma chest X-ray can be significantly impaired by the supine position of the patients. They argued that up to $30 \%$ of pneumothoraces were missed by supine radiographs. In our study, anterior-posterior chest X-ray was ordered in 102 patients, and 58.8\% of these were ordered as routine tests. There was no pathologic finding in any of them. In 9 patients, there was a pathologic finding in the anterior-posterior chest $\mathrm{X}$-ray. Among these 9 patients, the resident physician suspected a pathologic finding in 7 patients and he/ she was not sure about the examination in the other 2 patients. Finally, the NPV of the physical examination of the thorax-cardiovascular system was $96.5 \%$ when it was compared with the result of anterior-posterior chest X-ray.

Since mortality can be as high as $40 \%$, routine pelvic X-ray is suggested in the evaluation of blunt trauma patients according to ATLS protocols..$^{\left[{ }^{6,2}\right]}$ Ersoy et al. ${ }^{[5]}$ studied the necessity of pelvic X-ray in a series of 65 blunt trauma patients. All of the patients with pelvic fracture complained about pain, and in all of them, tenderness was also revealed during the examination. In their study, Salvino et al. ${ }^{[23]}$ determined that $92 \%$ of the patients with pelvic fracture were symptomatic. At the same time, in $1 \%$ of the asymptomatic patients, there was a pelvic fracture. Because of these issues, Salvino et al. argued that pelvic X-ray is unnecessary for patients who are alert and have no pain in their history or on pelvic examination. Gonzalez et al. ${ }^{[2]}$ evaluated 2176 patients with a GCS of $14-15$ for the presence of pelvic fracture. From the entire study population, a total of 97 patients $(4.5 \%)$ were diagnosed with pelvic fractures. There were 7 (sensitivity 93\%) missed pelvic fractures on clinical examination, with 13 (sensitivity 87\%) missed pelvic fractures by anterior-posterior radiography, and these were determined to be significant. Kessel et al. ${ }^{[25]}$ compared pelvic CT and pelvic X-ray. They determined that CT of the abdomen and pelvis identified $35.6 \%$ more pelvic fractures than the pelvic X-ray. Compared to CT, the sensitivity and specificity of the pelvic X-ray were $64 \%$ and $90 \%$, respectively. This supports the idea that CT is more helpful in the presence of suspicion of a pelvic fracture, and routine pelvic X-ray does not affect the treatment. In our study, if there was no pathologic finding on the pelvic examination, the possibility of a normal pelvic X-ray was determined as significantly higher. The NPV of the pelvic examination was high (96.8\%); however, the PPV was $50.0 \%$.

In the evaluation of the abdomen, ATLS suggests FAST. FAST is a portable, instantly appraisable, reliable, repeatable method, and does not disrupt resuscitation. At the same time, it gives extensive and dynamic diagnostic information. The major limitation of FAST is that it is operator-dependent. Furthermore, it is also patient-dependent; imaging is difficult in some patients. In determining abdominal free fluid, the sensitivity of FAST varies between $42-98 \%$, and the specificity is $95-100 \%{ }^{\left[{ }^{[26]}\right.}$ In our study, abdominal US was ordered for 80 patients. In 45 patients, abdominal US was ordered as a routine test. For 9 out of the remaining 35 patients, the resident physician suspected a pathology, and in 26 patients, the resident physician was not sure about the abdominal examination. Of the 80 patients who received abdominal US, pathologic findings were determined in only 4 patients. Of these 4 patients, 1 had splenic contusion, 2 had liver lacerations and 1 had parenchymal contusion with evident perihepatic and perisplenic fluid.

One of the greatest contributions of ATLS protocols in trauma is to relieve the physician. However, it has been seen that most of the routine tests are reported as normal. When targeted tests were done, the number of the patients who escaped notice was very few and the pathologies in these patients were not clinically important.

A deficiency of our study is that the number of patients was limited and the study was a unicentral study. Similar studies, which are more extensive and conducted in larger populations, should be done to study the use of targeted tests.

In conclusion, in recent years, many studies were conducted on the use of diagnostic tests and cost-effectiveness, not only in trauma patients, but also related to other medical issues. The importance of the subject is becoming better understood. With this study, we wanted to question if we can diagnose the pathology in a trauma patient in the quickest manner and with a limited number of tests; however, each additional test means additional time spent. In the ED, time is synonymous with life. Loss of time with unnecessary tests that make no difference in the treatment of the patient can be harmful. Furthermore, they decrease the quality of patient care that the medical personnel conducts. According to our study, biochemical tests, anterior-posterior chest X-ray and anterior-posterior 
pelvic X-ray can be ordered as targeted tests. Conducting targeted tests will reduce costs and workload. This will also contribute positively to a prospective effect in the area of health care. We believe that studies will be more informative if they are repeated in larger populations for longer periods, if they are supported by follow-up of the patients after the period in the ED, and if they are compared with gold standard methods.

\section{REFERENCES}

1. Committee on Injury Prevention and Control Division of health Promotion and Disease Prevention. In: Bonnie RJ, Fulco CE, Liverman CT, editors. Reducing the Burden of Injury; 1-17. Advencing Prevention and Treatment. Washington, DC: National Academy Pres; 1999.

2. Ertekin C. Multipl travmalı hastaya yaklaşım. Yoğun Bakım Dergisi 2002;2:77-87.

3. Ergene U, Fowler J. Costeffectivity of diagnostic tests in emergency medicine. 1st ed. [Çeviri Editörü: Oktay C]. Isparta: Süleyman Demirel Üniversitesi Yayınları; No: 3, 1999. s. 11-15.

4. Tasse JL, Janzen ML, Ahmed NA, Chung RS. Screening laboratory and radiology panels for trauma patients have low utility and are not cost effective. J Trauma 2008;65:1114-6.

5. Ersoy G, Karcioğlu O, Enginbaş Y, User N. Should all patients with blunt trauma undergo 'routine' pelvic X-ray? Eur J Emerg Med 1995;2:65-8. CrossRef

6. American College of Surgeons Committee on Trauma. Advanced trauma life support for doctors student course manual. 7th ed. Chicago: American College of Surgeons; 2004.

7. Chu UB, Clevenger FW, Imami ER, Lampard SD, Frykberg ER, Tepas JJ 3rd. The impact of selective laboratory evaluation on utilization of laboratory resources and patient care in a level-I trauma center. Am J Surg 1996;172:558-63. CrossRef

8. Snyder HS. Significance of the initial spun hematocrit in trauma patients. Am J Emerg Med 1998;16:150-3. CrossRef

9. Snyder HS, Dresnick SJ. Lack of tachycardic response to hypotension in penetrating abdominal injuries. J Emerg Med 1989;7:335-9. CrossRef

10. Mackersie RC, Dicker RA. Pitfalls in the evaluation and management of the trauma patient. Curr Probl Surg 2007;44:778833. CrossRef

11. Michetti CP, Sakran JV, Grabowski JG, Thompson EV, Bennett K, Fakhry SM. Physical examination is a poor screening test for abdominal-pelvic injury in adult blunt trauma patients. J Surg Res 2010;159:456-61. CrossRef

12. Keller MS, Coln CE, Trimble JA, Green MC, Weber TR. The utility of routine trauma laboratories in pediatric trauma resuscitations. Am J Surg 2004;188:671-8. CrossRef

13. Karaduman D, Sarioglu-Buke A, Kilic I, Gurses E. The role of elevated liver transaminase levels in children with blunt abdominal trauma. Injury 2003;34:249-52. CrossRef

14. Bent C, Iyngkaran T, Power N, Matson M, Hajdinjak T, Buchholz N, et al. Urological injuries following trauma. Clin Radiol 2008;63:1361-71. CrossRef

15. Saltzherr TP, Fung Kon Jin PH, Beenen LF, Vandertop WP, Goslings JC. Diagnostic imaging of cervical spine injuries following blunt trauma: a review of the literature and practical guideline. Injury 2009;40:795-800. CrossRef

16. Ersoy G, Karcioğlu O, Enginbaş Y, Eray O, Ayrik C. Are cervical spine $\mathrm{X}$-rays mandatory in all blunt trauma patients? Eur J Emerg Med 1995;2:191-5. CrossRef

17. Bandiera G, Stiell IG, Wells GA, Clement C, De Maio V, Vandemheen $\mathrm{KL}$, et al. The Canadian $\mathrm{C}$-spine rule performs better than unstructured physician judgment. Ann Emerg Med 2003;42:395-402. CrossRef

18. Duane TM, Dechert T, Brown H, Wolfe LG, Malhotra AK, Aboutanos MB, et al. Is the lateral cervical spine plain film obsolete? J Surg Res 2008;147:267-9. CrossRef

19. Kortbeek JB, Al Turki SA, Ali J, Antoine JA, Bouillon B, Brasel K, et al. Advanced trauma life support, 8th edition, the evidence for change. J Trauma 2008;64:1638-50. CrossRef

20. Dickinson G, Stiell IG, Schull M, Brison R, Clement CM, Vandemheen KL, et al. Retrospective application of the NEXUS low-risk criteria for cervical spine radiography in Canadian emergency departments. Ann Emerg Med 2004;43:507-14. CrossRef

21. Rezende-Neto JB, Hoffmann J, Al Mahroos M, Tien H, Hsee LC, Spencer Netto F, et al. Occult pneumomediastinum in blunt chest trauma: clinical significance. Injury 2010;41:403. CrossRef

22. American College of Surgeons Committee on Trauma. Advanced trauma life support. Chicago; 1990.

23. Salvino CK, Esposito TJ, Smith D, Dries D, Marshall W, Flisak M, et al. Routine pelvic x-ray studies in awake blunt trauma patients: a sensible policy? J Trauma 1992;33:4136. CrossRef

24. Gonzalez RP, Fried PQ, Bukhalo M. The utility of clinical examination in screening for pelvic fractures in blunt trauma. J Am Coll Surg 2002;194:121-5. CrossRef

25. Kessel B, Sevi R, Jeroukhimov I, Kalganov A, Khashan T, Ashkenazi I, et al. Is routine portable pelvic X-ray in stable multiple trauma patients always justified in a high technology era? Injury 2007;38:559-63. CrossRef

26. Rippey JC, Royse AG. Ultrasound in trauma. Best Pract Res Clin Anaesthesiol 2009;23:343-62. CrossRef 